\title{
Molecular Diversity Study in CMS-A, Maintainer-B and Restorer-R Lines in Pigeon Pea [Cajanus cajan (L.) Millsp.]
}

\author{
Mayur Gadekar ${ }^{1 *}$, Rohit Jadhav ${ }^{2}$, Milind Meshram², \\ Shreekant Amarshettiwar ${ }^{2}$, Ashok Patil ${ }^{2}$ and Ravindra Nandanwar ${ }^{2}$ \\ ${ }^{1}$ Nimbkar Agricultural Research Institute, Phaltan, Maharashtra, India \\ ${ }^{2}$ Department of Agricultural Botany, Post Graduate Institute, Dr. P.D.K.V., \\ Akola, Maharashtra, India \\ *Corresponding author
}

\section{A B S T R A C T}

\begin{tabular}{|c|c|}
\hline & Twenty eight lines including $8 \mathrm{~A}$ lines, $8 \mathrm{~B}$-lines and $12 \mathrm{R}$-lines newly developed at station \\
\hline & $\begin{array}{l}\text { were characterized by with } 21 \text { SSR primers. A total number of alleles detected by the } \\
\text { aforesaid primers were } 63 \text { with maximum and minimum frequency of } 5 \text { and } 2 \text {, }\end{array}$ \\
\hline $\begin{array}{l}\text { Molecular diversity, } \\
\text { Pigeon pea. }\end{array}$ & $\begin{array}{l}\text { respectively. The maximum and minimum PIC Values were found to be } 0.994 \text { and } 0.138 \\
\text { for the primers CCB-3 and CCB-5 respectively. Average genetic similarity coefficient }\end{array}$ \\
\hline Article Info & $\begin{array}{l}\text { from all possible combinations was found to be } 0.563 \text {. Among the } 21 \text { primers, } 9 \text { were } \\
\text { found polymorphic for } 28 \text { genotypes. Genetic similarity coefficient for most of number of }\end{array}$ \\
\hline $\begin{array}{l}\text { Accepted: } \\
07 \text { October } 2017 \\
\text { Available Online: } \\
10 \text { December } 2017\end{array}$ & $\begin{array}{l}\text { pairs was in the range of } 0.86 \text { to } 1.00 \text {, indicating diversity among the chosen genotypes. } \\
\text { All the } 28 \text { genetic lines could be easily distinguished from each other based on the selected } \\
\text { markers and thus were effective for varietal identification and diversity analysis of } \\
\text { pigeonpea genotypes. A dendogram based on loci profile showed good agreement with } \\
\text { their cultivars pedigree information. }\end{array}$ \\
\hline
\end{tabular}

\section{Introduction}

Genetic diversity is the basis for launching an efficient breeding programme that aimed for the improvement of crop productivity. Crop breeding through hybridization also requires the selection of diverse genotypes, irrespective of whether the product is a pure line or a hybrid variety (Zeb et al., 2009). The use of molecular markers for the evaluation of genetic diversity is very common. Simple sequence repeats (SSRs) have been widely exploited in wheat due to their high level of polymorphisms, co-dominant inheritance and equal distribution in the wheat genome (Khaled et al., 2015). SSRs are more abundant, ubiquitous in presence, hyper- variable in nature and have high polymorphic information content (PIC) (Gupta et al., 2009). SSR have been used to study genetic diversity of pigeonpea cultivar by Burns et al., (2001), Odeny et al., (2007), Songok et al., (2010), Saxena et al., (2010) and for wheat cultivars by Grewal et al., 2007; Hai et al., 2007; Ijaz and Khan, 2009; Khaled et al., 2015; Mohammadi et al., 2009.

Microsatellites or simple sequence repeats (SSRs) provide an efficient tool in diversity studies for identifying the degree of genetic similarity. Due to their high rate of polymorphism, co-dominant character, 
selective neutrality, distribution across the genome and cost and labor efficiency, microsatellites markers are suitable for detecting allele frequency within the population and for assessing population structure (Khaled et al., 2015).

At present, SSR is one of most promising molecular markers which are able to identify or differentiate genotypes within a species. SSRs are ubiquitously interspersed in eukaryotic genomes and can find applications as highly variable and multi allelic PCR based genetic markers. The high level of polymorphism and easy handling has made SSRs extremely useful for different applications in crop improvement (Gupta et al., 2009). Keeping in view the advantage of SSR markers the present research work was carried out to study genetic variation among A, B and R-lines of pigeonpea using specific SSR markers and to find relationship of molecular diversity with the heterosis. These CMS lines (A), maintainer lines (B) and restorer lines (R) were morphologically diverse. Lines were selected to find out the diversity among the twenty eight genetic lines at molecular level using twenty one SSR primers.

\section{Materials and Methods}

\section{Plant material}

Total twenty eight lines including eight CMS lines (four leaf variants CMS lines and four height variant CMS lines), eight $\mathrm{B}$ lines of respective CMS lines and twelve restorer lines (Table 1). These eight CMS lines were morphologically diverse were developed recently through backcross breeding at Pulses Research Centre, Dr. Panjabrao Deshmukh Krishi Vidyapeeth, Akola, Maharashtra. Four leaf variant CMS lines are Oval leaf CMS, Sesame leaf CMS, Obcordifoliate CMS and Small leaf CMS lines (Fig. 1) these lines had different leaf shapes and four height variant CMS lines are Dwarf $30 \mathrm{~cm}$, Dwarf $45 \mathrm{~cm}$, Dwarf $60 \mathrm{~cm}$ and Dwarf $90 \mathrm{~cm}$ (Fig. 2) were showing height variation. Seed were grown in cups in green house upto 10-12 leaf stage for DNA extraction.

\section{DNA extraction}

Fresh leaf samples $(2 \mathrm{~g})$ were collected from each lines for DNA extraction. Total genomic DNA was isolated by CTAB method. Visual confirmation and quantification of DNA samples was done by using $0.8 \%$ agarose gel electrophoresis. High concentration of DNA samples was further diluted in 10:1 TrisEDTA to a working concentration of 25 $\mathrm{ng} / \mu \mathrm{L}$ and stored at $4^{\circ} \mathrm{C}$ for PCR based marker analysis.

\section{PCR Amplification}

PCR amplification was performed on each 28 $\mathrm{A}, \mathrm{B}$ and $\mathrm{R}$-lines of pigeonpea using each SSR locus. Procedure of DNA amplification given by Sambrook and Russell, 2006 was followed. A total of 21 pairs of primers flanking the satellite region were used for the genetic diversity assessment is give in the Table 2. One primer pair was selected from each linkage group. PCR reaction was prepared with 25-30 ng of pigeonpea genomic DNA, $2 \mu 1$ of $3^{\prime}$ and $5^{\prime}$ end primers, $10 \mathrm{mM}$ of each dNTP, $10 \times$ PCR buffer containing KCL, $25 \mathrm{mM} \mathrm{MgCl} 2$ and one unit of Taq polymerase in a total of $20 \mu \mathrm{l}$ solution individually for all 21 primers pair. PCR thermal cycler was programmed for $30 \mathrm{sec}$ at $94^{\circ} \mathrm{C}, 30 \mathrm{sec}$ at $44-55^{\circ} \mathrm{C}$ and $45 \mathrm{sec}$ at $72^{\circ} \mathrm{C}$ and final cycle of $7 \mathrm{~min}$ at $72^{\circ} \mathrm{C}$ with 40 cycles for each primer. The amplified products were resolved on $8 \%$ PAGE on a Vertical Gel Electrophoresis System. After electrophoresis, the gels were stained using silver staining (0.3 gm Silver Nitrate). To resolve the SSR products, the silver staining 
was carried out following Tagelstrom (1992). A 100bp DNA ladder was used to estimate the size of each band.

\section{Statistical analysis}

DNA bands were scored which were formed in the range of expected amplified product size given for each particular primer. Amplified bands were numbered according to their migration within the gel. For each genotype, the presence or absence of each bands was determined and scored ' 1 ' if present and ' 0 ' if absent. Similarities between any 2 genotypes were estimated according to Jaccard (1908) as. The similarity of sample was calculated as-

$\mathrm{S}_{\mathrm{AB}}=\frac{2 \mathrm{~N}_{\mathrm{AB}}}{\mathrm{N}_{\mathrm{A}}+\mathrm{N}_{\mathrm{B}}}$

Where,

$\mathrm{S}_{\mathrm{AB}}=$ The similarity index

$\mathrm{N}_{\mathrm{AB}}=$ The number of bands shared by individuals $\mathrm{A}$ and $\mathrm{B}$

$\mathrm{NA}$ and $\mathrm{NB}=$ The total number of bands in individual $\mathrm{A}$ and $\mathrm{B}$ respectively

Dendogram was constructed based on the SAB values by adopting the Sequential Agglomerative Hierarchical Non-overlapping (SAHN) clustering technique of unweighted pair groups method of arithmetic mean (UPGMA). These computations were performed using the statistical analysis package NTSYS-pc Var 2.02i (Rohlf, 1998). Polymorphic information content (PIC) refers to the value of a SSR marker for detecting polymorphism within a population. PIC depends on the number of detectable alleles and the distribution of their frequency (Botstein et al., 1980). The value was calculated as,
$\mathrm{PICi}=1-\sum_{\mathrm{j}=1}^{\mathrm{n}} \mathrm{P}_{\mathrm{ij}}^{2}$

Where,

PICi is the polymorphic information content of a marker $i, P_{i j}$ is the frequency of the $j^{\text {th }}$ pattern for marker $i$ and the summation extent over $n$ pattern.

\section{Results and Discussion}

Twenty one SSR primers of Axygen Biosciences were used to evaluate 28 parental genotypes of pigeonpea involve $8 \mathrm{CMS}$ lines, 8 maintainer lines and 12 restorer lines.

The PCR amplified products of each primer were resolved on $8 \%$ polyacrylamide gel electrophoresis (PAGE) and the size of the amplified products was compared with DNA molecular weight marker 100 bp ladder (Fermentas).

Out of 21 SSR primers screened during present study, 12 primers viz., CCB-10, CCttc001，CCtta001，CCtta002，CCtta003, CCcat001, ICPM1A08, ICPM1B04_a, ICPM1C02, ICPM1D10, ICPM1F11, ICPM1G04 were found monomorphic and nine primers viz., CCB-2, CCB-3, CCB-4, CCB-5, CCB-6, CCB-7, CCB-8, CCB-9 and CCttat001 were found polymorphic for the set of selected genotypes.

\section{Polymorphic Information Content (PIC)}

Total 63 alleles were detected among the 28 genotypes under the investigation. The polymorphic information content (PIC) value of 9 SSR loci were calculated across 28 pigeonpea genotypes and is presented in Table 2. As a result, 9 markers showed polymorphism in 28 parental lines analyzed. These polymorphic markers amplified a total of 28 alleles (in expected range of band size) with an average of 3.1 alleles per marker. 
Table.1 List of genotypes for SSR molecular analysis

\begin{tabular}{|c|l|l|l|}
\hline Sr. No. & \multicolumn{1}{|c|}{ cms lines } & \multicolumn{1}{c|}{ Maintainer lines } & \multicolumn{1}{|c|}{ Restore lines } \\
\hline 1 & Oval leaf-A & Oval leaf-B & AKPR-249 \\
\hline 2 & Sesamum leaf-A & Sesamum leaf-B & AKPR-178 (E) \\
\hline 3 & Obcordifoliate Leaf-A & Obcordifoliate Leaf-B & AKPR-12 \\
\hline 4 & Small Leaf-A & Small Leaf-B & AKPR-178 (M) \\
\hline 5 & Dwarf $30 \mathrm{~cm}-\mathrm{A}$ & Dwarf $30 \mathrm{~cm}-\mathrm{B}$ & AKPR-344 \\
\hline 6 & Dwarf $45 \mathrm{~cm}-\mathrm{A}$ & Dwarf $45 \mathrm{~cm}-\mathrm{B}$ & AKPR-8 \\
\hline 7 & Dwarf. $60 \mathrm{~cm}-\mathrm{A}$ & Dwarf $60 \mathrm{~cm}-\mathrm{B}$ & AKPR-210 \\
\hline 8 & Dwarf $90 \mathrm{~cm}-\mathrm{A}$ & Dwarf $90 \mathrm{~cm}-\mathrm{B}$ & AKPR-325 \\
\hline 9 & & & AKPR-364 \\
\hline 10 & & & AKPR-319 \\
\hline 11 & & & AKPR-359 \\
\hline 12 & & & AKPR-292 \\
\hline
\end{tabular}

Table.2 SSR polymorphism among male sterile (A), maintainer (B) and restorer (R) lines

\begin{tabular}{|c|c|c|c|c|c|c|c|}
\hline \multirow{2}{*}{$\begin{array}{l}\text { SSR } \\
\text { markers }\end{array}$} & \multirow{2}{*}{$\begin{array}{c}\text { A- lines } \\
\text { No. of } \\
\text { alleles }\end{array}$} & \multirow{2}{*}{$\begin{array}{c}\text { B- lines } \\
\text { No. of } \\
\text { alleles }\end{array}$} & \multirow{2}{*}{$\begin{array}{l}\text { R- lines } \\
\text { No. of } \\
\text { alleles }\end{array}$} & \multirow[b]{2}{*}{$\begin{array}{c}\text { PIC } \\
\text { value }\end{array}$} & \multirow{2}{*}{$\begin{array}{c}\text { All lines } \\
\text { No. of } \\
\text { alleles }\end{array}$} & \multicolumn{2}{|c|}{ Band Size (bp) } \\
\hline & & & & & & Observed & Expected \\
\hline CCB-2 & 3 & 3 & 3 & 0.325 & 3 & $131-182$ & $154-165$ \\
\hline CCB-3 & 3 & 3 & 3 & 0.994 & 3 & $245-288$ & $117-121$ \\
\hline CCB-4 & 3 & 3 & 3 & 0.382 & 4 & $231-264$ & $216-236$ \\
\hline CCB-5 & 3 & 3 & 3 & 0.138 & 3 & $192-226$ & $185-207$ \\
\hline CCB-6 & 4 & 4 & 4 & 0.202 & 4 & $193-240$ & $202-208$ \\
\hline CCB-7 & 3 & 3 & 3 & 0.968 & 3 & $151-187$ & $152-160$ \\
\hline CCB-8 & 3 & 3 & 3 & 0.897 & 3 & $118-145$ & $138-148$ \\
\hline CCB-9 & 4 & 4 & 4 & 0.897 & 4 & $159-208$ & $148-174$ \\
\hline CCB-10 & 3 & 3 & 3 & - & 3 & $240-292$ & $244-250$ \\
\hline CCttc001 & 5 & 5 & 5 & - & 5 & $152-204$ & $185-220$ \\
\hline $\mathrm{CCtta001}$ & 4 & 4 & 4 & - & 4 & $224-320$ & 220 \\
\hline $\mathrm{CCtta002}$ & 2 & 2 & 2 & - & 2 & $234-251$ & $240-320$ \\
\hline $\mathrm{CCtta003}$ & 2 & 2 & 2 & - & 2 & $147-172$ & $180-190$ \\
\hline CCcat001 & 3 & 3 & 3 & - & 3 & $153-243$ & $155-185$ \\
\hline CCttat001 & 3 & 3 & 3 & 0.265 & 3 & $208-249$ & $210-250$ \\
\hline ICPM1A08 & 2 & 2 & 2 & - & 2 & $295-330$ & $290-294$ \\
\hline ICPM1B04_a & 2 & 2 & 2 & - & 2 & $139-160$ & $108-178$ \\
\hline ICPM1C02 & 3 & 3 & 3 & - & 3 & $246-289$ & $272-294$ \\
\hline ICPM1D10 & 2 & 2 & 2 & - & 2 & $306-332$ & 294-330 \\
\hline ICPM1F11 & 2 & 2 & 2 & - & 2 & $238-275$ & $243-265$ \\
\hline ICPM1G04 & 3 & 3 & 3 & - & 3 & $100-171$ & $133-158$ \\
\hline
\end{tabular}


Table.3 Grouping of genotypes at 96 per cent similarity index

\begin{tabular}{|c|c|l|}
\hline $\begin{array}{c}\text { Super Cluster } \\
\text { No. }\end{array}$ & \multicolumn{1}{|c|}{$\begin{array}{c}\text { No. of } \\
\text { genotypes }\end{array}$} & \multicolumn{1}{|c|}{ Genotypes included is respective clusters } \\
\hline I & 4 & Oval leaf A, Oval leaf B, Sesamum leaf A, Sesamum Leaf B \\
\hline II & 12 & $\begin{array}{l}\text { Obcordifoliate leaf A, AKPR-8, Small leaf A, Small leaf B, Dwarf 30 cm A, } \\
\text { Dwarf } 30 \mathrm{~cm} \mathrm{B,} \mathrm{Dwarf} \mathrm{45} \mathrm{cm} \mathrm{A,} \mathrm{Dwarf} \mathrm{45} \mathrm{cm} \mathrm{B,} \mathrm{Dwarf} \mathrm{60} \mathrm{cm} \mathrm{A,} \mathrm{Dwarf} 90 \mathrm{~cm} \\
\text { A, Dwarf } 60 \mathrm{~cm} \mathrm{B,} \mathrm{AKPR-364.}\end{array}$ \\
\hline III & 3 & AKPR-210, AKPR-325, AKPR-319 \\
\hline IV & 1 & Obcordifoliate leaf B \\
\hline V & 3 & AKPR-178 (M), AKPR-344, AKPR-292 \\
\hline VI & 1 & Dwarf 90 cm B \\
\hline VII & 1 & AKPR-249 \\
\hline VIII & 1 & AKPR-178 (E) \\
\hline IX & 1 & AKPR-12 \\
\hline X & 1 & AKPR-359 \\
\hline
\end{tabular}

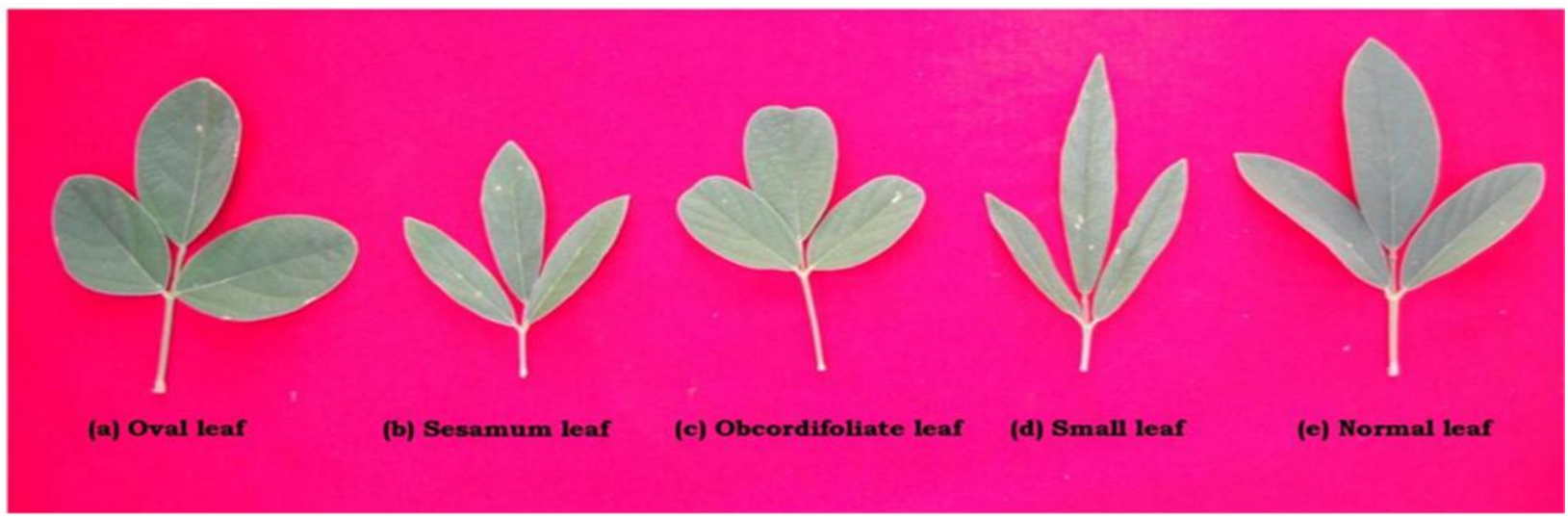

Fig.1: Different leaf shape CMS \& B-lines (a) Oval leaf A \& B lines (b) Sesamum Leaf A \& B lines (c)

Ob cordifoliate leaf A \& B-lines (d) Small leaf A \& B-lines (e) Normal lanceolatus leaf shape (12 restor er lines)
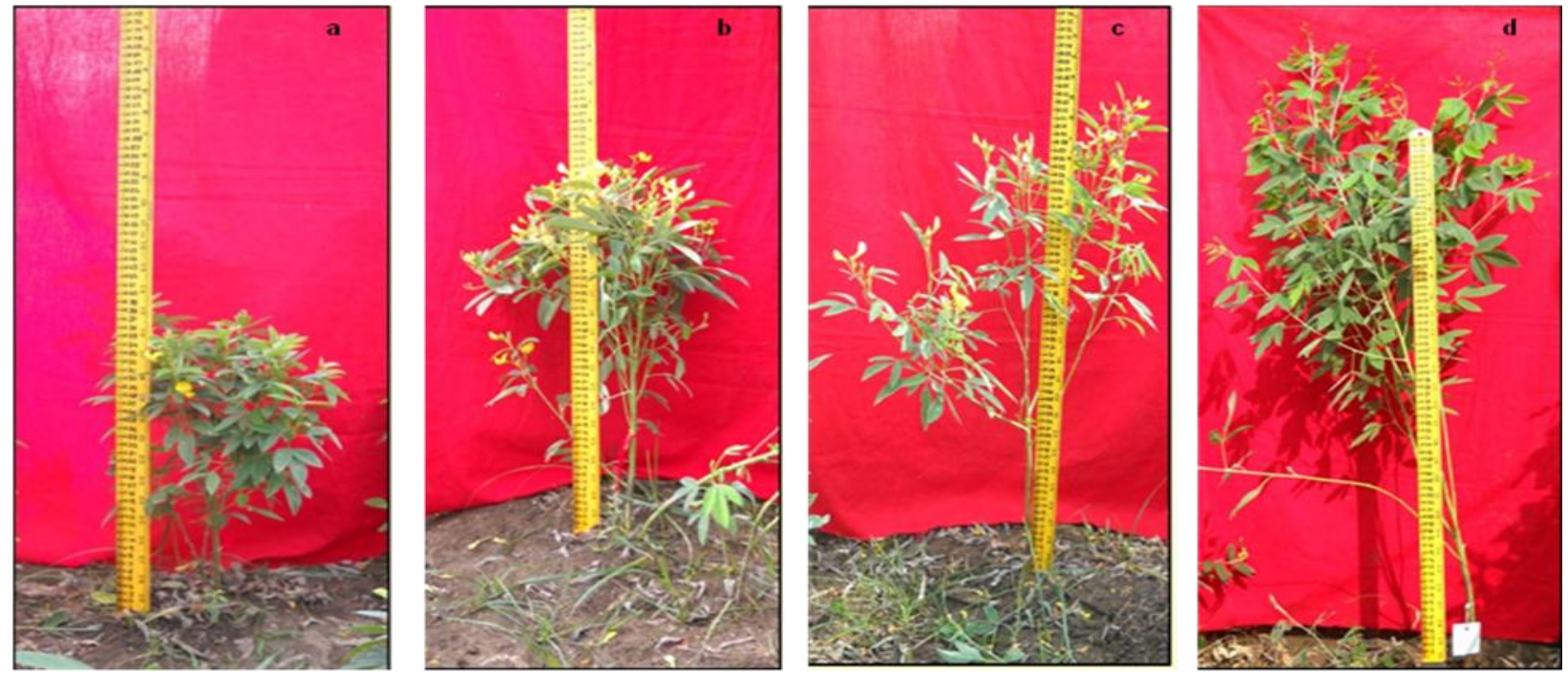

Fig. 2: Differ ent height variants CMS \& B-lines (a) Dw arf $30 \mathrm{~cm} A$ \& $B$ lines (b) Dwarf $45 \mathrm{~cm} A$ \& $B$ lines (c) Dw arf $60 \mathrm{~cm} A$ \& $B$ lines (d) Dw arf $90 \mathrm{~cm} A$ \& $B$ lines 


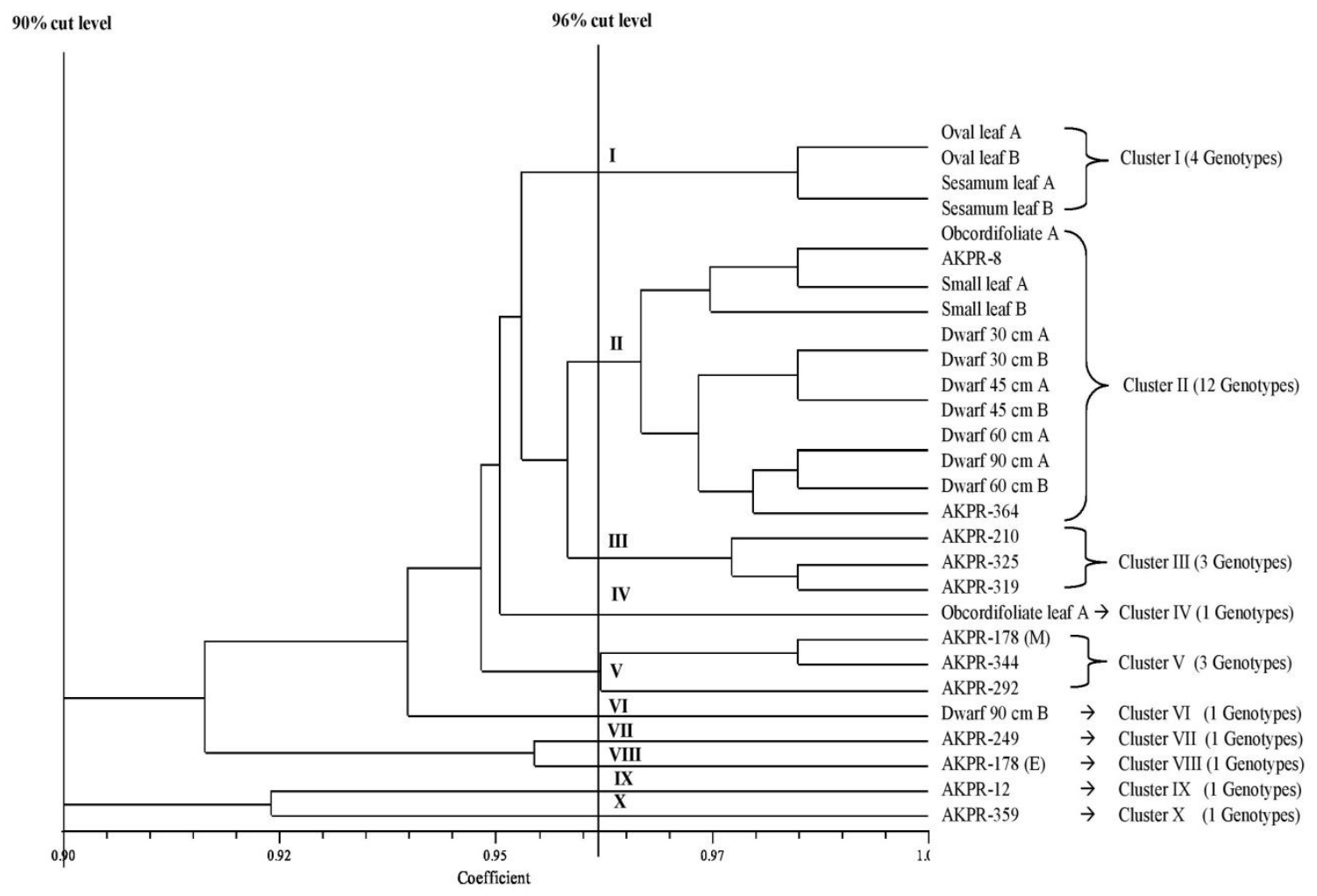

Fig.3: Dendogram of phylogenic tree of A, B and R lines of pigeonpea obtained by UPGMA method on the basis of SSR markers

Eleven markers (11) amplified 3 alleles, six primers amplified 2 alleles while a maximum of 5 alleles were amplified by one marker (CCttc001). Bands were considered under expected base pair size only. The PIC values calculated for these 9 polymorphic primers were in the range of 0.138 (CCB-6) to 0.994 (CCB-3) with an average of 0.563 per marker.

In present study four primers viz., CCB-3 (0.994), CCB-7 (0.968), CCB-8 (0.897), CCB-9 (0.897) showed high PIC values indicating their utility for assessment of genetic diversity. Thus it is necessary to obtained information about genetic diversity from polymorphic primers only so that genetically divergent genotypes can be effectively identified. Odeny et al., (2009) recorded 0.72 highest PIC value and similarly, 0.658 PIC value were recorded by
Songok et al., (2010) for CCB-4 primer of SSR markers in pigeonpea.

The size of the bands amplified with selected primers was found in between 118 and $320 \mathrm{bp}$ when compared with DNA molecular weight $100 \mathrm{bp}$ ladder. All the bands were observed in the ranges of expected size. A total of 63 alleles were obtained with an average of 3.1 alleles per locus. Similar results in expected size were observed by Burns et al., (2001), Odeny et al., (2007), Songok et al., (2010), Saxena et al., (2010). The average number of alleles per locus was 3.14 found by Odoney et al., (2009). Previous diversity analysis of cultivated pigeonpea species reported an average of 3.10 for 10 polymorphic loci (Burn et al., 2001) and 3.4 for 9 polymorphic loci (Odoney et al., 2007) which are similar to the present results in expected range. 


\section{Genetic relation}

Genetic relationship between pigeonpea genotypes was determined on the basis of Jaccards pair wise similarity coefficient values. The value of similarity coefficient for 28 pigeonpea ranged from 0.86 to 1.00 . Cluster analysis was performed to elucidate the relationship among the genotypes and the dendrogram was prepared in Figure 3. The twenty eight pigeonpea parental genotypes were grouped into two super clusters at 90 per cent cut level of similarity. In super cluster 1 , maximum similarity coefficient was 1.00 shared by Oval leaf A and Oval leaf B; Sesamum leaf A and Sesamum leaf B; Dwarf $30 \mathrm{~cm} \mathrm{~A}$ and Dwarf $30 \mathrm{~cm} \mathrm{~B}$; Dwarf $45 \mathrm{~cm} \mathrm{~A}$ and Dwarf $45 \mathrm{~cm} \mathrm{~B}$ also Dwarf $90 \mathrm{~cm} \mathrm{~A} \mathrm{and}$ Dwarf $60 \mathrm{~cm} \mathrm{~A}$; Obcordifoliate leaf A and AKPR-8 shared 1.00 similarity coefficient. Minimum similarity coefficient was 0.87 which was shared by most of the genotypes (Table 2). Super cluster 2 at 90 per cent cut level included two genotypes. The similarity coefficient between AKPR-12 and AKPR-359 was 0.92 .

Further, these 28 genotypes diverged into 10 clusters at approximately 96 per cent level of similarity. Among these 10 clusters the largest cluster was cluster II (12 genotypes), cluster I include 4 genotypes, cluster III and V includes three genotypes and cluster IV, VI, VII, VIII, IX and $\mathrm{X}$ includes only one genotypes (Table 3 and Fig. 3).

CMS lines and respective maintainer lines are genetically similar except for one fertility locus. Similarly in the present study most of the paired CMS lines and respective maintainer lines were clustered in the same group. Twenty eight SSR primers used for screening the molecular diversity among 28 genetic lines showed sufficient genetic diversity with 63 alleles over the genome and $\mathrm{A}$ and R-lines are diverse from each other.
A total 63 alleles were found for 21 SSR marker screening among the twenty eight $\mathrm{A}$, $\mathrm{B}$ and R- lines of pigeon pea. Similarity coefficients were ranged from 0.86 to 1.00 for twenty eight parental lines. It showed that the parental lines showed clear morphological difference but at the genetic level these parents showed maximum similarity especially for 21 loci. Abundant genetic diversity is present among the twenty eight genotypes for 21 SSR primers used in the present investigations and will be useful to characterize the A, B and R-lines.

\section{References}

Bostein, D., R.L. White, M. Skohmick and R.W. Davis, 1980: Construction of genetic linkage map in man using restriction fragment length polymorphism. Am J. Hum. Genet. 32, 314-332.

Burns M.J., K.J. Edwards, H.J. Newbury, B.V. Ford-Lloyd and C.D. Baggott, 2001: Development of simple sequence repeat (SSR) markers for the assessment of gene flow and genetic diversity in pigeonpea (Cajanus cajan). Molecular Ecology Notes. 1, 283-285.

Grewal, S., P. Kharb, R. Malik, S. Jain and R. K. Jain, 2007: Assessment of genetic diversity among some Indian wheat cultivars using random amplified polymorphic DNA (RAPD) markers. Indian. J. Biotech. 6, 18-23.

Gupta, P. K., Peter Langridge and R.R. Mir, 2009: Marker-assisted wheat breeding: present status and future possibilities. Mol Breed. DOI 10.1007/s11032-0099359-7.

Hai, L., C. Wagner, and W. Friedt, 2007: Quantitative structure analysis of genetic diversity among spring bread wheats (Triticum aestivum L.) from different geographical regions. Genetica, 130, 213-225. 
http://dx.doi.org/10.1007/s10709-0069008-6.

Ijaz, S., and I. A. Khan, 2009: Molecular characterization of wheat germplasm using microsatellite markers. Genetics and Molecular Research. 8, 809-815. http://dx.doi.org/10.4238/vol8-3gmr60 8.

Jaccard, P., 1908. Nauvelles researchers sur la distribution florate. Bull Soc Vaud Sci. Nat. 44, 223-270.

Khaled F. M. Salem, S. R. Marion and A. Börner, 2015: Assessing genetic diversity of Egyptian hexaploid wheat (Triticum aestivum L.) using microsatellite markers. Genetic Resources and Crop Evolution. 62, 377385

Mohammadi, S. A., M. Khodarahmi, S. Jamalirad and M. R. Jalal Kamali, 2009: Genetic diversity in a collection of old and new bread wheat cultivars from Iran as revealed by simple sequence repeatbased analysis. Annals of Applied Biology. 154, 67-76. http://dx.doi.org/ 10.1111/j.1744-7348.2008.00273.x.

Odeny, D.A., B. Jayashree, C. Gebhardt, and J. Crouch. 2009: New microsatellite markers for pigeonpea (Cajanus cajan (L.) millsp.). BMC Res. Notes. 2, 35.

Odeny, D.A., B. Jayashree, M. Ferguson, D. Hoisington, J. Crouch, and C. Gebhardt, 2007: Development, characterization and utilization of microsatellite markers in pigeonpea. Plant Breed. 126,130-137.
Rohlf, F.J., 1998: NTSYS-PC numerical taxonomy and multivariate analysis system, version 2.02, Extra Publications, Setauket, NY.

Sambrook, J. and D.W. Russell, 2006: Molecular Cloning: a laboratory manual. Cold Spring Harber, New York. 1 and 2: 5.41-5.48 and 8.12-8.22

Saxena R.K., C. Prathima, K.B. Saxena, D.A. Hoisington, N.K. Singh and R. K. Varshney, 2010: Novel SSR Markers for Polymorphism Detection in Pigeonpea (Cajanus spp.). Plant Breeding. 129, 142-148.

Songok S., M. Ferguson, A.W. Muigai and S. Silim, 2010: Genetic diversity in pigeonpea [Cajanus cajan (L.) Millsp.] Landraces as revealed by simple sequence repeat markers. African Journal of Biotechnology. 9, 32313241.

Tagelstrom, H, 1992: Detection of mitichodrial DNA fragments. In Hoelzel AR (ed.) molecular genetic analysis of populations. A practical approach, IRL Press, Oxford, pp: 89114.

Zeb, B., I. A. Khan, S. Ali, S. Bacha, S. Mumtaz and Z. A. Swati, 2009: Study on genetic diversity in Pakistani wheat varieties using simple sequence repeat (SSR) markers. African Journal of Biotechnology. 8, 4016-4019.

\section{How to cite this article:}

Mayur Gadekar, Rohit Jadhav, Milind Meshram, Shreekant Amarshettiwar, Ashok Patil and Ravindra Nandanwar. 2017. Molecular Diversity Study in CMS-A, Maintainer-B and RestorerR Lines in Pigeon Pea [Cajanus cajan (L.) Millsp.]. Int.J.Curr.Microbiol.App.Sci. 6(12): 500507. doi: https://doi.org/10.20546/ijcmas.2017.612.061 